\title{
Bosea minatitlanensis sp. nov., a strictly aerobic bacterium isolated from an anaerobic digester
}

Correspondence Aboubakar S. Ouattara ouattabs@univ-ouaga.bf

\author{
Aboubakar S. Ouattara, ${ }^{1}$ Essokazi A. Assih, ${ }^{1,4}$ Sébastien Thierry, ${ }^{2,3}$ \\ Jean-Luc Cayol, ${ }^{4}$ Marc Labat, ${ }^{4}$ Oscar Monroy ${ }^{2}$ and Hervé Macarie ${ }^{2,3}$
}

${ }^{1}$ Département de Biochimie-Microbiologie, Unité de Formation et de Recherches en Sciences de la Vie et de la Terre, Université de Ouagadougou, 03 BP 7021, Ouagadougou 03, Burkina Faso

${ }^{2}$ Departamento de Biotecnología, Universidad Autónoma Metropolitana-Iztapalapa, Avenida Michoacán y la Purisima s/n, Col. Vicentina, 09340 México DF, Mexico

${ }^{3}$ Institut de Recherche pour le Développement (IRD), Cicerón 609, Col. Los Morales, 11530 México DF, Mexico

${ }^{4}$ Laboratoire de Microbiologie IRD, IFR-BAIM, Universités de Provence et de la Méditerranée, ESIL case 925, 163, avenue de Luminy, 13288 Marseille cedex 9, France
The genus Bosea is phylogenetically placed in the $\alpha$-Proteobacteria (Das et al., 1996; Stubner et al., 1998). It was initially described with one species, Bosea thiooxidans, isolated from agricultural soils as a free-living microorganism that was capable of oxidizing reduced inorganic sulfur compounds (Das et al., 1996). Later, a strain designated 5Z2111, which was closely related to B. thiooxidans (97.3\% 16S rRNA sequence similarity), was isolated from rice field soil (Stubner et al., 1998). Isolate 5Z2111 differs from the type strain of $B$. thiooxidans in its ability to grow autotrophically with $\mathrm{CO}_{2}$ as a carbon source. Comparing all the characteristics of the type strain of $B$. thiooxidans and strain 5Z2111, the authors assumed that the latter probably represented a separate species and perhaps genus.

Abbreviations: CFA, cellular fatty acid; UASB reactor, upflow anaerobic sludge blanket reactor.

The GenBank accession number for the $16 \mathrm{~S}$ rRNA gene sequence of strain $A M X 51^{\top}$ is $A F 273081$.
To our knowledge, the taxonomic status of strain $5 \mathrm{Z} 2111$ as a novel species of Bosea has not been established, and this strain is not available in any public collection.

During a study of the role of strictly aerobic bacteria in anaerobic digesters, enumeration and identification of these micro-organisms were performed using a laboratoryscale upflow anaerobic sludge blanket (UASB) reactor fed with the wastewater of a petrochemical company producing purified terephthalic acid. Eighty-five strains were isolated and subjected to identification by classical biochemical methods, analysis of the cellular fatty acids (CFA) and/or partial 16S rRNA gene sequence analysis. The taxonomic methods used could identify $87 \%$ of the isolates accurately. Comparison of the CFA profiles of the unknown strains by unweighted arithmetic average clustering allowed separation of the strains into two groups. All of the strains in the first group were later shown to belong to one species, Stenotrophomonas acidaminiphila (Assih et al., 2002). The second group was represented by a single isolate, strain AMX 
$51^{\mathrm{T}}\left(=\right.$ DSM $13099^{\mathrm{T}}=$ ATCC $700918^{\mathrm{T}}=$ CIP $\left.106457^{\mathrm{T}}\right)$. This strain was then subjected to more-detailed taxonomic study. Its characterization is reported as the type strain of a novel species of the genus Bosea, Bosea minatitlanensis sp. nov.

Strain AMX $51^{\mathrm{T}}$ was isolated from the anaerobic sludge of a laboratory-scale UASB reactor using R2A medium (Oxoid). Purification and culture procedures were described elsewhere (Assih et al., 2002). B. thiooxidans DSM $9653^{\mathrm{T}}$ and Afipia felis DSM $7326^{\mathrm{T}}$ were obtained from the DSMZ. Procedures for analytical techniques, determination of general phenotypic characteristics, antibiotic susceptibility, DNA G + C content and CFA composition, 16S rRNA sequencing and DNA-DNA hybridization are described elsewhere (Assih et al., 2002). Thiosulfate oxidation was tested in basal medium (Assih et al., 2002) with maltose or Casamino acids as substrate. Additional biochemical analysis was performed by inoculating Biotype 100 strips (bioMérieux) according to the manufacturer's instructions. Biotype medium 1 was used for inoculum preparation. For phylogeny, a non-redundant BLASTN search (Altschul et al., 1997) of the full sequence through GenBank and EMBL (Benson et al., 1999) identified its closest relatives. Sequence data were imported into the sequence editor BioEdit version 5.0.9 (Hall, 1999); the bases were examined and a contiguous consensus sequence was generated for each isolate. The full sequence was aligned using the RDP Sequence Aligner program (Maidak et al., 2001). The consensus sequence was then adjusted manually to conform to the 16S rRNA secondary structure model (Winker \& Woese, 1991). Sequences used in the phylogenetic analysis were obtained from the RDP (Maidak et al., 2001) and GenBank (Benson et al., 1999). Positions of sequence and alignment ambiguity were omitted and pairwise evolutionary distances based on 1350 unambiguous nucleotides (16S rRNA) were calculated using the method of Jukes \& Cantor (1969). Dendrograms were constructed using the neighbour-joining method (Saitou \& Nei, 1987). Confidence in the tree topology was determined using 100 bootstrapped trees (Felsenstein, 1985).

After 2-10 days at $30^{\circ} \mathrm{C}$, strain AMX $51^{\mathrm{T}}$ formed nonpigmented, circular colonies on trypticase soy or R2A agar. Growth was not accompanied by odour. Further attempts to obtain other colonies or strains with phenotypic characteristics similar to those of strain AMX $51^{\mathrm{T}}$ were unsuccessful. Such results suggest that this bacterium was probably only a transient micro-organism in the reactor, which was fed with non-sterilized wastewater, from which it was isolated. Cells of isolate AMX $51^{\mathrm{T}}$ were straight to curved rods, slowly motile and stained Gramnegative. Electron microscopy observations showed that the cell wall structure of the isolate was typical of Gramnegative bacteria and indicated a monotrichous polar flagellation type (data not shown). Spore formation was not observed. Cells occurred singly or in pairs and were $0 \cdot 5 \times 1 \cdot 5-2 \cdot 0 \mu \mathrm{m}$ in size. Strain AMX $51^{\mathrm{T}}$ was strictly aerobic, as shown by the absence of growth after 1 month incubation at $35^{\circ} \mathrm{C}$ in an anaerobic jar on R2A medium. Growth was observed between 15 and $42^{\circ} \mathrm{C}$, with optimum growth at $37^{\circ} \mathrm{C}$. No growth occurred at $\leqslant 4$ or $\geqslant 45^{\circ} \mathrm{C}$. The $\mathrm{pH}$ range for growth was $5 \cdot 0-8 \cdot 5$, with optimum growth at $\mathrm{pH} 6 \cdot 0$. The maximum growth rate determined in rich medium (Assih et al., 2002) was approximately $0.237 \mathrm{~h}^{-1}$ at $37^{\circ} \mathrm{C}$, pH $7 \cdot 0$, and $0 \cdot 201 \mathrm{~h}^{-1}$ at $35^{\circ} \mathrm{C}$, pH $6 \cdot 0$. Strain AMX $51^{\mathrm{T}}$ was positive for oxidase, catalase, urease and amylase and weakly proteolytic. Tests for nitrite reductase, nitrate reductase, indole production, aesculin, Simmons' citrate, ONPG, lysine decarboxylase, ornithine decarboxylase, arginine dihydrolase, DNase and Tween 80 esterase were negative. The substrate utilization tests performed on API 20NE and Biotype 100 strips or in defined basal liquid medium (Assih et al., 2002) showed that strain AMX $51^{\mathrm{T}}$ was able to use several amino acids, organic acids and methanol (for detailed list, see below). Discrepancies in the utilization of substrates were observed between the different tests. Whereas utilization of L-histidine, L-serine, L-tyrosine and succinate was positive in Biotype 100, these tests were negative in the defined medium, and vice versa for L-aspartate, fumarate, glycerol and propionate. Assimilation of all other substrates present on Biotype 100 (i.e. 74 out of 99) was negative. Negative results were also obtained for assimilation of choline, L-isoleucine, DL-leucine, L-methionine, D-ornithine, DL-threonine, DLvaline, oxalate and starch tested in basal liquid medium and adipate tested with API 20NE. With the API 50CH strips, none of the substrates was acidified after 9 days incubation. Thiosulfate oxidation was observed in the presence of succinate and Casamino acids. The striking feature of these results is that, under all culture conditions tested (API 20NE, API 50CH, Biotype 100, defined basal medium), none of the sugars tested could be used as a substrate by strain AMX $51^{\mathrm{T}}$.

Phenotypic similarities shared by B. thiooxidans DSM $9653^{\mathrm{T}}$ and strain AMX $51^{\mathrm{T}}$ included cell shape, the presence of catalase and oxidase, thiosulfate oxidation, utilization of L-glutamate, D-gluconate, L-malate, D-malate, L-proline, DL-alanine, L-arginine, L-cysteine, L-glutamine, L-asparagine, acetate and pyruvate and the absence of indole production and arginine dihydrolase. Up to 21 phenotypic differences could be observed between $B$. thiooxidans DSM $9653^{\mathrm{T}}$ and strain AMX $51^{\mathrm{T}}$, including nitrate reductase activity, Simmons' citrate test (citrate assimilation), starch and gelatin hydrolysis, utilization of lactate, adipate, phenylacetate and sugars and growth above $41{ }^{\circ} \mathrm{C}$ (Table 1). Susceptibility of strain AMX $51^{\mathrm{T}}$ to the following antibiotics was observed: imipenem $(10 \mu \mathrm{g})$, cephalothin $(30 \mu \mathrm{g})$, cefotaxime $(30 \mu \mathrm{g})$, ticarcillin $(75 \mu \mathrm{g})$, tobramycin $(10 \mu \mathrm{g})$, amikacin $(30 \mu \mathrm{g})$, gentamicin $(10 \mathrm{IU})$, netilmicin $(30 \mu \mathrm{g})$, colistin $(300 \mathrm{IU})$, piperacillin/tazobactam $(75 / 10 \mu \mathrm{g})$ and trimethoprim/sulfamethoxazole $(1 \cdot 25 / 23 \cdot 75 \mu \mathrm{g})$. Isolate AMX $51^{\mathrm{T}}$ was resistant to ceftazidime $(30 \mu \mathrm{g})$, ofloxacin $(5 \mu \mathrm{g})$ and ciprofloxacin $(5 \mu \mathrm{g})$. Intermediate responses were observed with piperacillin $(75 \mu \mathrm{g})$, amoxicillin $(25 \mu \mathrm{g})$ and amoxicillin/clavulanic acid $(25 / 10 \mu \mathrm{g})$. 
Table 1. Characteristics that differentiate strain AMX $51^{\top}$ from B. thiooxidans DSM $9653^{\top}$

Data for B. thiooxidans from Das et al. (1996). Characteristics are scored as: + or -, test is positive/negative, substrate is used/not used; $\mathrm{W}$, weakly positive.

\begin{tabular}{|lcc|}
\hline Characteristic & Strain AMX $\mathbf{5 1}^{\mathbf{T}}$ & B. $^{\text {thiooxidans }}$ DSM $\mathbf{9 6 5 3}{ }^{\mathbf{T}}$ \\
\hline Growth requirements & Casamino acids & Glutamate + yeast extract \\
Nitrate reduction & - & + \\
Simmons' citrate & $\mathrm{W}$ & + \\
Hydrolysis of starch and gelatin & + & - \\
Utilization of phenylalanine, DL-lactate, methanol & - & - \\
Utilization of sugars, $N$-acetylglucosamine, adipate, phenylacetate* & + & - \\
Growth below $20{ }^{\circ} \mathrm{C}$ and at $42{ }^{\circ} \mathrm{C}$ & 37 & $30-32$ \\
Optimal temperature for growth $\left({ }^{\circ} \mathrm{C}\right)$ & $6 \cdot 0$ & $7 \cdot 5-8 \cdot 0$ \\
Optimal pH for growth & & + \\
\hline
\end{tabular}

${ }^{\star}$ Sugars tested were D-glucose, D-fructose, D-galactose, L-sorbose, L-arabinose, D-xylose, D-ribose, L-rhamnose, D-mannose and maltose.

The predominant CFA found in strain AMX $51^{\mathrm{T}}$ were $\mathrm{C}_{18: 1} \omega 7 c(56 \cdot 56 \%), \mathrm{C}_{19: 0}$ cyclo $\omega 8 c \quad(13 \cdot 27 \%), \mathrm{C}_{16: 0}$ $(9 \cdot 64 \%), \mathrm{C}_{16: 0} 3-\mathrm{OH}(4 \cdot 64 \%)$ and $\mathrm{C}_{18: 1} \omega 7 c$ 11-methyl $(4 \cdot 55 \%)$. This CFA pattern is similar to that of B. thiooxidans DSM $9653^{\mathrm{T}}$ (Table 2). Notable differences in the their CFA profiles are in levels of $\mathrm{C}_{18: 1} \omega 7 c$ 11-methyl, $\mathrm{C}_{17: 1} \omega 8 c$ and $\mathrm{C}_{17: 0}$ (Table 2). The Euclidian distance of 12 between the CFA profiles of isolate AMX $51^{\mathrm{T}}$ and B. thiooxidans DSM $9653^{\mathrm{T}}$ suggests that they are linked at the genus level, but not at the species level. The CFA profile of the novel isolate was significantly different from that of $A$. felis, which can be considered as a representative

Table 2. Fatty acid profiles of strain $A M X 51^{\top}$ and B. thiooxidans DSM $9653^{\mathrm{T}}$

Values are percentages of total fatty acids. Data were determined in this study.

\begin{tabular}{|lcc|}
\hline Fatty acid & $\begin{array}{r}\text { Strain } \\
\text { AMX } \mathbf{5 1} \mathbf{T}^{\mathbf{T}}\end{array}$ & $\begin{array}{c}\text { B. thiooxidans } \\
\text { DSM } \mathbf{9 6 5 3}^{\mathbf{T}}\end{array}$ \\
\hline $13: 1 \omega 1 c$ & $0 \cdot 72$ & $0 \cdot 24$ \\
$14: 0$ & $0 \cdot 23$ & $0 \cdot 19$ \\
$15: 0$ & $1 \cdot 06$ & $1 \cdot 16$ \\
$15: 03-\mathrm{OH}$ & $0 \cdot 43$ & $0 \cdot 35$ \\
$16: 0$ & $9 \cdot 64$ & $6 \cdot 60$ \\
$16: 03-\mathrm{OH}$ & $4 \cdot 64$ & $3 \cdot 34$ \\
$16: 1 \omega 7 c / 15: 0$ iso $2-\mathrm{OH}$ & $2 \cdot 50$ & $3 \cdot 49$ \\
$17: 0$ & $1 \cdot 33$ & $3 \cdot 35$ \\
$17: 03-\mathrm{OH}$ & $0 \cdot 27$ & $0 \cdot 59$ \\
$17: 0$ cyclo & $2 \cdot 91$ & $2 \cdot 03$ \\
$17: 1 \omega 8 c$ & $0 \cdot 87$ & $2 \cdot 77$ \\
$18: 0$ & $0 \cdot 36$ & $0 \cdot 49$ \\
$18: 1 \omega 7 c$ & $56 \cdot 56$ & $64 \cdot 64$ \\
$18: 1 \omega 7 c 11-m e t h y l$ & $4 \cdot 55$ & $0 \cdot 39$ \\
$19: 0$ cyclo $\omega 8 c$ & $13 \cdot 27$ & $9 \cdot 67$ \\
$19: 0$ 10-methyl & $0 \cdot 63$ & $0 \cdot 72$ \\
\hline
\end{tabular}

of the genus Afipia (data not shown). The Euclidian distance found during CFA analysis between strain AMX $51^{\mathrm{T}}$, $B$. thiooxidans and $A$. felis was about 50-52. Such results confirm that these species cannot belong to the same genus, which is consistent with other phenotypic data.

The $\mathrm{G}+\mathrm{C}$ content of isolate AMX $51^{\mathrm{T}}$ was $68 \cdot 5 \pm 0 \cdot 4 \mathrm{~mol} \%$ (three determinations). This value is close to that reported for B. thiooxidans DSM $9653^{\mathrm{T}}(68.2 \mathrm{~mol} \%)$ (Das et al., 1996) and a closely related bacterium, strain 5Z2111 $(66 \cdot 45 \pm 0 \cdot 05 \%)$ (Stubner et al., 1998). A total of 1482 positions of its $16 \mathrm{~S}$ rRNA gene was sequenced. Phylogenetic analysis revealed that strain AMX $51^{\mathrm{T}}$ is member of the $\alpha$-2 subgroup of Proteobacteria. Among species with validly published names, its closest relatives were B. thiooxidans DSM $9653^{\mathrm{T}}$, Methylobacterium organophilum JCM $2833^{\mathrm{T}}$, Methylobacterium mesophilicum JCM $2829^{\mathrm{T}}$, Afipia clevelandensis DSM $7315^{\mathrm{T}}$ and A. felis DSM $7326^{\mathrm{T}}$, with respective similarity levels of $98 \cdot 88,92 \cdot 70,92 \cdot 61,91 \cdot 67$ and $91.59 \%$ (Fig. 1). As isolate AMX $51^{\mathrm{T}}$ shares $91-93 \%$ $16 \mathrm{~S}$ rRNA sequence similarity with $M$. organophilum JCM $2833^{\mathrm{T}}$, M. mesophilicum JCM $2829^{\mathrm{T}}$, A. clevelandensis DSM $7315^{\mathrm{T}}$ and $A$. felis DSM $7326^{\mathrm{T}}$, it cannot be member of any of these species (Stackebrandt \& Goebel, 1994). The phenotypic differences observed between the isolate and the above-mentioned species are sufficient to exclude its affiliation to the genera Methylobacterium and Afipia; this result correlates with the phylogeny results. The high $16 \mathrm{~S}$ rRNA sequence similarity $(98 \cdot 88 \%)$ found between strain AMX $51^{\mathrm{T}}$ and B. thiooxidans DSM $9653^{\mathrm{T}}$ correlates with the similarities observed in phenotypic traits and CFA profiles. In accordance with this, it is proposed that strain AMX $51^{\mathrm{T}}$ should be affiliated to the genus Bosea. Since the relatively high $16 \mathrm{~S}$ rRNA sequence similarity $(98 \cdot 88 \%)$ did not allow discrimination of strain AMX $51^{\mathrm{T}}$ from B. thiooxidans DSM $9653^{\mathrm{T}}$ at the species level (Stackebrandt \& Goebel, 1994), DNA-DNA hybridization analysis was used to resolve the genomic relationships. DNA-DNA hybridization revealed $44 \cdot 2 \%$ similarity with $B$. thiooxidans 


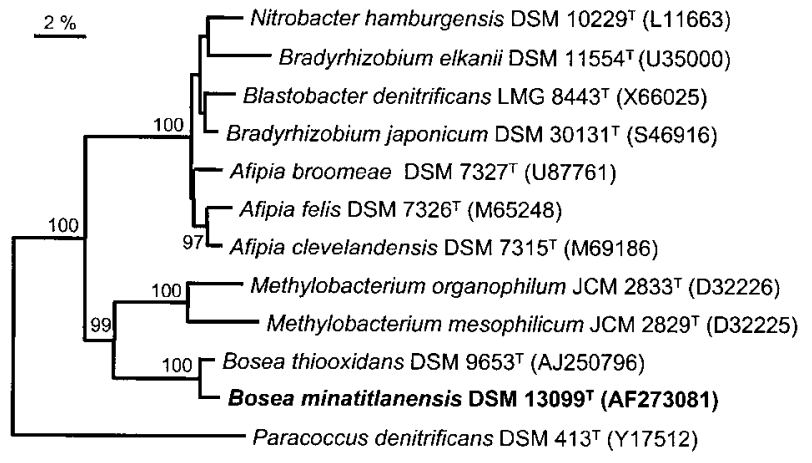

Fig. 1. Phylogenetic dendrogram showing the position of strain AMX $51^{\top}$ (=DSM 13099 $)$ among closely related species of Proteobacteria. Bar, 2 nt substitutions per 100 nt. Numbers at nodes correspond to bootstrap percentages based on 100 resamplings. Only values greater than $80 \%$ were considered significant and are therefore reported.

DSM $9653^{\mathrm{T}}$. This value is high enough to support affiliation of strain AMX $51^{\mathrm{T}}$ to the genus Bosea. However, since the DNA-DNA hybridization value observed is significantly below $70 \%$, it is concluded that strain AMX $51^{\mathrm{T}}$ represents a separate species (Stackebrandt et al., 2002; Wayne et al., 1987). In contrast, the DNA-DNA hybridization values found between AMX $51^{\mathrm{T}}$ and A. felis $(15 \cdot 1 \%)$ and between B. thiooxidans DSM $9653^{\mathrm{T}}$ and A. felis $(19 \cdot 6 \%)$ are very low. Such results, combined with general phenotypic characteristics, CFA profiles and $16 \mathrm{~S}$ rRNA sequence similarity values, support the conclusion that the novel isolate and B. thiooxidans are not members of the genus Afipia.

\section{Description of Bosea minatitlanensis sp. nov.}

Bosea minatitlanensis (mi.na.tit.lan.en'sis. N.L. minatitlanensis of Minatitlán, a town in the south of Veracruz state in Mexico, where the anaerobic sludge of a pilot-scale reactor was sampled to inoculate the lab-scale UASB reactor from which the type strain was isolated).

Cells are straight to curved rods, $0 \cdot 5 \times 1 \cdot 5-2 \cdot 0 \mu \mathrm{m}$. Gramnegative, non-sporulating, motile, strictly aerobic bacterium. Monotrichous polar flagellation. Circular, non-pigmented colonies on trypticase soy or R2A agar. Growth is not accompanied by odour. Thiosulfate oxidation is observed in presence of succinate or Casamino acids. Positive for oxidase, catalase and urease; weakly positive for amylase and proteolysis; negative for nitrite reductase, nitrate reductase, indole production, Simmons's citrate, ONPG, aesculin, lysine decarboxylase, ornithine decarboxylase, arginine dihydrolase, DNase and Tween 80 esterase. All API $50 \mathrm{CH}$ tests are negative. Amino acids (Casamino acids, L-alanine, L-arginine, L-asparagine, L-cysteine, L-glutamate, L-glutamine, L-phenylalanine and L-proline) and organic acids (acetate, 4-aminobutyrate, crotonate, formate, D-galacturonate, D-gluconate, D-glucuronate, glutarate,
DL-glycerate, 3-hydroxybutyrate, 2-ketogluconate, 2oxoglutarate, DL-lactate, D-malate, L-malate and pyruvate) are utilized as substrates, as well as methanol, but sugars are not. Casamino acids are required as nitrogen source. Susceptible to imipenem, cephalothin, cefotaxime, ticarcillin, tobramycin, amikacin, gentamicin, netilmicin, piperacillin/ tazobactam, trimethoprim/sulfamethoxazole and colistin. Resistant to ceftazidime, ofloxacin and ciprofloxacin. Intermediate responses are observed for piperacillin and amoxicillin/clavulanic acid. Growth is observed between 15 and $42{ }^{\circ} \mathrm{C}$, with an optimum at $37^{\circ} \mathrm{C}$. No growth at $\leqslant 4$ or $\geqslant 45^{\circ} \mathrm{C}$. The $\mathrm{pH}$ range for growth is $5 \cdot 0-8 \cdot 5$; optimum $\mathrm{pH}$ 6.0. Predominant CFA are $\mathrm{C}_{18: 1} \omega 7 c, \mathrm{C}_{19: 0}$ cyclo $\omega 8 c$, $\mathrm{C}_{16: 0}, \mathrm{C}_{16: 0} 3-\mathrm{OH}$ and $\mathrm{C}_{18: 1} \omega 7 c$ 11-methyl. The $\mathrm{G}+\mathrm{C}$ content of the type strain is $68 \cdot 5 \pm 0 \cdot 4 \mathrm{~mol} \%$.

The type strain, AMX $51^{\mathrm{T}}\left(=\mathrm{DSM} \quad 13099^{\mathrm{T}}=\mathrm{ATCC}\right.$ $\left.700918^{\mathrm{T}}=\mathrm{CIP} 106457^{\mathrm{T}}\right)$, is an environmental bacterium, probably originating from soil or water, that was isolated as a transient micro-organism from anaerobic sludge of a lab-scale UASB reactor treating the petrochemical wastewater of a purified terephthalic acid plant in Minatitlán (Mexico).

\section{Acknowledgements}

For the realization of this work, A.S.O. received post-doctoral fellowships from the IRD. S.T. was supported financially by the IRD and the Secretaria de Relaciones Exteriores (Foreign Affairs) of Mexico. Thanks are due to Martine Keridjian and Anne Le Flèche of the Pasteur Institute and Nicolas Fortineau of Pasteur Cerba for determination of some of the biochemical characteristics and antibiotic susceptibility of strain AMX $51^{\mathrm{T}}$. We wish to thank Pierre Thomas for electron microscope facilities and Frédéric Verhe for technical assistance and Marie Laure Fardeau, Jean Le Mer and Jean-Louis Garcia for fruitful discussions. Special thanks are due to Karen Dohrman of Microbial ID, John Bartell of MIDI Labs and Peter Schumann of DSMZ for suggestions about CFA, 16S rRNA sequences and DNA hybridization analysis, respectively. Fernando Varela and Roberto Marcelo from Tereftalatos Mexicanos SA, who gave us the wastewater and inoculum for the operation of the lab-scale reactor from which strain AMX $51^{\mathrm{T}}$ was isolated, are gratefully acknowledged.

\section{References}

Altschul, S. F., Madden, T. L., Schäffer, A. A., Zhang, J., Zhang, Z., Miller, W. \& Lipman, D. J. (1997). Gapped BLAST and PSI-BLAST: a new generation of protein database search programs. Nucleic Acids Res 25, 3389-3402.

Assih, E. A., Ouattara, A. S., Thierry, S., Cayol, J.-L., Labat, M. \& Macarie, H. (2002). Stenotrophomonas acidaminiphila sp. nov., a strictly aerobic bacterium isolated from an upflow anaerobic sludge blanket (UASB) reactor. Int J Syst Evol Microbiol 52, 559-568.

Benson, D. A., Boguski, M. S., Lipman, D. J., Ostell, J., Ouellette, B. F. F., Rapp, B. A. \& Wheeler, D. L. (1999). GenBank. Nucleic Acids Res 27, 12-17.

Das, S. K., Mishra, A. K., Tindall, B. J., Rainey, F. A. \& Stackebrandt, E. (1996). Oxidation of thiosulfate by a new bacterium, Bosea thiooxidans (strain BI-42) gen. nov., sp. nov.: analysis of phylogeny based on chemotaxonomy and 16S ribosomal DNA sequencing. Int J Syst Bacteriol 46, 981-987. 
Felsenstein, J. (1985). Confidence limits on phylogenies: an approach using the bootstrap. Evolution 39, 783-791.

Hall, T. A. (1999). BioEdit: a user-friendly biological sequence alignment editor and analysis program for Windows 95/98/NT. Nucleic Acids Symp Ser 41, 95-98.

Jukes, T. H. \& Cantor, C. R. (1969). Evolution of protein molecules. In Mammalian Protein Metabolism, vol. 3, pp. 21-132. Edited by H. N. Munro. New York: Academic Press.

Maidak, B. L., Cole, J. R., Lilburn, T. G. \& 7 other authors (2001). The RDP-II (Ribosomal Database Project). Nucleic Acids Res 29, 173-174.

Saitou, N. \& Nei, M. (1987). The neighbor-joining method: a new method for reconstructing phylogenetic trees. Mol Biol Evol 4, 406-425.

Stackebrandt, E. \& Goebel, B. M. (1994). Taxonomic note: a place for DNA-DNA reassociation and $16 \mathrm{~S}$ rRNA sequence analysis in the present species definition in bacteriology. Int $J$ Syst Bacteriol 44, 846-849.

Stackebrandt, E., Frederiksen, W., Garrity, G. M. \& 10 other authors (2002). Report of the ad hoc committee for the re-evaluation of the species definition in bacteriology. Int $J$ Syst Evol Microbiol 52, 1043-1047.

Stubner, S., Wind, T. \& Conrad, R. (1998). Sulfur oxidation in rice field soil: activity, enumeration, isolation and characterization of thiosulfate oxidizing bacteria. Syst Appl Microbiol 21, 569-578.

Wayne, L. G., Brenner, D. J., Colwell, R. R. \& 9 other authors (1987). International Committee on Systematic Bacteriology. Report of the ad hoc committee on reconciliation of approaches to bacterial systematics. Int J Syst Bacteriol 37, 463-464.

Winker, S. \& Woese, C. R. (1991). A definition of the domains Archaea, Bacteria and Eucarya in terms of small subunit ribosomal RNA characteristics. Syst Appl Microbiol 14, 305-310. 